\title{
Hygroscopicity of the bark of selected forest tree species
}

\author{
Anna llek, \\ Jaroslaw Kucza, \\ Karolina Morkisz
}

\begin{abstract}
As the outer layer of trees and shrubs, bark is exposed to the direct action of atmospheric conditions and reacts to changes in relative air humidity. This study focuses on the actual hygroscopicity of the bark, regarded as a component of the total bark retention capability. The main research aims were to: (1) determine the physical properties (specific density, bulk density, total porosity), actual hygroscopicity and maximum water storage capacity of the stem bark at breast height $(1.3 \mathrm{~m})$ of eight forest tree species; $(2)$ assess the relationship between bark actual hygroscopicity and its physical properties; (3) determine the share of the actual hygroscopicity of bark in its maximum water storage capacity. Significant differences were observed among the different species considered as a consequence of the variation in physical properties of their bark. Actual hygroscopicity of bark (expressed in balance units), i.e., the maximum water amount that can be absorbed from saturated air by the outer bark layer, showed a significant relationship with bark physical properties. Depending on tree species, actual hygroscopicity may constitute from 10 to $30 \%$ of the maximum water storage capacity of bark.
\end{abstract}

Keywords: Forest Hydrology, Forest Tree Bark, Bark Actual Hygroscopicity, Bark Water Storage Capacity

ment of numerous organisms, such as mosses, lichens and plasmodial slime molds, whose distribution over the tree stem depends primarily on tree species, bark texture and bark acidity (Bates \& Brown 1981, Stephenson 1989, Kuusinen 1996, Öztürk \& Oran 2011).

Individual tree species differ from one another in terms of bark thickness and texture. The morphological differentiation of bark also occurs within a single species (Ilek \& Kucza 2014). As a result of tree stem thickening, cracks appear in bark and become deeper with tree age, and the direction of cracks determines the appearance of bark (Kubiak \& Laurow 1994). Although the tree bark surface structure is relatively difficult to parametrize, methods of its measurement have been recently developed. It can currently be measured using the LaserBark ${ }^{\mathrm{TM}}$ device (Van Stan et al. 2010), which enables automatic and fast measurement of bark microrelief, wavelet analysis (Legates et al. 2014) and the coefficient of development of the interception be used in air pollution biomonitorin (Schulz et al. 1999) and it is the environ-

$\square$ Department of Forest Engineering, Institute of Forest Ecosystem Protection, Faculty of Forestry, University of Agriculture in Krakow, Al. 29 Listopada 46, 31425 Krakow (Poland)

@ Anna Ilek (a.ilek@wp.pl)

Received: Jan 12, 2016 - Accepted: Jul 07, 2016

Citation: Ilek A, Kucza J, Morkisz K (2017). Hygroscopicity of the bark of selected forest tree species. iForest 10: 220-226. - doi: 10.3832/ifor1979-009 [online 2016-11-06]

Communicated by: Giacomo Goli surface of bark (Ilek \& Kucza 2014).

From the point of view of forest hydrology, tree and shrub bark is one of the basic containers which intercept rainwater. Rainfall interception on the plant surface is an important component of the hydrological cycle of the forest environment and depends, among others, on species-related characteristics of plants (leaf size and arrangement, bark roughness), weather conditions, rainfall amount and intensity as well as raindrop size (Herwitz 1985, Levia \& Frost 2003, Levia \& Herwitz 2005, Klamerus-Iwan 2014). The amount of water stored on the plant surface may reach from 6 to $50 \%$ of total rainfall (Liu 1997, Llorens et al. 1997, Aboal et al. 1999, Bryant et al. 2005) and the key role in that process is played by the bark layer of trees (Herwitz 1985, Llorens \& Gallart 2000).

Bark structure differences between particular tree species affect the water storage capacity of bark and stemflow production (Brown \& Barker 1970, Barbier et al. 2009, Levia et al. 2010). According to some authors, the maximum water capacity of bark and its wettability are factors affecting the volume and chemistry of the water flowing down the tree stem (Voigt \& Zwolinski 1964, Crockford \& Richardson 2000, Levia \& Herwitz 2005). The condition necessary for water flow down the stem is the saturation of its bark with water (Kozlowski et al. 2010). According to Voigt \& Zwolinski (1964) the amount of water flowing down the tree stem depends more on bark properties than on meteorological conditions. It has been observed that trees with rough bark have a higher water storage 
capacity and generate a smaller stemflow than trees with smooth bark (Voigt 1960, Levia \& Frost 2003, Levia \& Germer 2015). Van Stan et al. (2015) used a LaserBark to compute bark microrelief, ridge-to-furrow amplitude and slope metrics for Fagus sylvatica L. and Quercus robur L. They observed that a smaller ridge-to-furrow amplitude and slope for Fagus sylvatica significantly lowered the bark water storage capacity, which strongly correlated to maximum funneling ratios and permitted stemflow generation at lower rain magnitudes, while larger ridge-to-furrow amplitude and slope values for Quercus robur reduce funneling, diminishing stemflow drainage for larger storms.

Despite a vast literature on plant interception, relatively little is known about the dynamics of rainfall interception by the bark of stems and branches and the factors that regulate this process. As the outer tree layer, bark is exposed to the direct action of atmospheric conditions and it reacts to changes in relative air humidity, often resulting in changes of bark thickness and moisture. For that reason, the object of the present research is the actual hygroscopicity of the bark of selected forest tree species, regarded as a component of the maximum water storage capacity of bark. Actual hygroscopicity $S_{\mathrm{HA}}$ should be understood as the maximum amount of water (expressed in balance units) that can be absorbed from saturated air by bark with particular physical characteristics, assuming that the water is adsorbed only by the outer bark layer, exposed to the direct action of atmospheric conditions. The main research aims include: (1) determination of physical properties (specific density, bulk density and total porosity), actual hygroscopicity and maximum water storage capacity of the stem bark at breast height $(1.3 \mathrm{~m})$ of eight forest tree species; (2) demonstration of the relationship between bark actual hygroscopicity and its physical properties; (3) determination of the share of the actual hygroscopicity of bark in its maximum water storage capacity.

\section{Materials and methods}

\section{The research area}

Bark samples were collected in Tokarnia Forest District ( $\left.49^{\circ} 46^{\prime} 28^{\prime \prime} \mathrm{N}, 19^{\circ} 51^{\prime} 51^{\prime \prime} \mathrm{E}\right)$, part of Myslenice Forest Division, south Poland. The research area is located in the $8^{\text {th }}$ Carpathian Province, District of the Beskid Makowski and Wyspowy Mts and in the Mezoregion of the Beskid Makowski Mts (Trampler et al. 1990). Bark samples were collected from the stems of living trees growing on a mixed mountain forest site, at the altitude from 550 to $800 \mathrm{~m}$ a.s.l.

\section{Test material sampling}

We focused our study on the bark of 4 coniferous tree species: Pinus sylvestris L., Larix decidua Mill., Abies alba Mill., Picea abies (L.) H. Karst and 4 deciduous tree species: Quercus robur L., Fagus sylvatica L., Acer pseudoplatanus L. and Betula pendula Ehrh. Test samples were collected after the beginning of the vegetation season (May June 2012) from the stems of living trees at breast height $(1.3 \mathrm{~m})$. The test material was collected using a saw, knives and chisels by cutting relatively regular bark pieces with the area ranging from 50 to $200 \mathrm{~cm}^{2}$, depending on the thickness of bark and trees. For each species, ten bark samples were collected from trees with the breastheight diameter from 5 to $60 \mathrm{~cm}$.

\section{Laboratory research}

In the laboratory, each sample was cut into three. One section was used to analyze the specific density $\left(\rho_{s}\right)$; the second to determine the bulk density $\left(\rho_{\mathrm{d}}\right)$, while the third was used in the analysis of the actual hygroscopicity $\left(S_{\mathrm{HA}}\right)$ and the maximum water storage capacity $\left(S_{\mathrm{v}}\right)$.

\section{Determination of specific density, bulk} density and total porosity

Specific density $\rho_{\mathrm{s}}$ of particular bark samples was determined by the standard pycnometer method (PKN-CEN-ISO/TS-17892-3 2009) - commonly used to determine the specific density of soil - after grinding the bark in a laboratory grinder and pulverizing it in a porcelain mortar. In order to increase measurement accuracy and prevent the flow of dry particles to the surface of the liquid, the $99.8 \%$ ethyl alcohol was used instead of water. Specific density $\rho_{\mathrm{s}}\left(\mathrm{g} \mathrm{cm}^{-3}\right)$ was calculated according to the following formula (eqn. 1):

$$
\rho_{s}=M_{s} / V_{s}
$$

where $M_{\mathrm{s}}$ is the dry mass of a pulverized bark sample, determined after its drying at $105^{\circ} \mathrm{C}(\mathrm{g})$ and $V_{\mathrm{s}}$ is the volume of the solid phase of a bark sample $\left(\mathrm{cm}^{3}\right)$.

In the present study, bulk density $\rho_{\mathrm{d}}$ is understood as the ratio of dry mass of the bark to its maximum volume, determined in the state of maximum swelling. According to Raczkowski (1979), pine bark reaches the state of maximum swelling after about 100 hours of soaking in water. For that reason, before determination of bulk density, bark samples were placed in containers with water for 5 days. Next, their volume was determined with the method of temporary augmentation of the water level in a cylinder, after which the samples underwent 24-hour drying at 105 ${ }^{\circ} \mathrm{C}$. The bulk density of bark $\rho_{\mathrm{d}}\left(\mathrm{g} \mathrm{cm}^{-3}\right)$ was determined by the formula (eqn. 2 ):

$$
\rho_{d}=M_{s} / V
$$

where $M_{\mathrm{s}}$ is the dry mass of bark determined after drying a sample at $105^{\circ} \mathrm{C}(\mathrm{g})$, and $V$ is the volume of a given bark sample determined in the state of maximum swelling $\left(\mathrm{cm}^{3}\right)$.

On the basis of specific density $\rho_{\mathrm{s}}$ and bulk density $\rho_{\mathrm{d}}$, for particular bark samples, total porosity $\left(T P, \mathrm{~cm}^{3} \mathrm{~cm}^{-3}\right)$ was determined using the formula (eqn. 3 ):

$$
T P=\frac{\rho_{s}-\rho_{d}}{\rho_{s}}
$$

\section{Actual hygroscopicity and maximum water storage capacity}

Before the beginning of experiments aimed at determination of actual hygroscopicity $S_{\mathrm{HA}}$ and maximum water storage capacity of bark $S_{\mathrm{V}}$, individual samples were dried for a few days at $35{ }^{\circ} \mathrm{C}$, until their mass stabilized. After their removal from the dryer, all samples were weighed and their internal and side surfaces were secured with silicone so that during the experiments the water was only adsorbed by their external layer. After the application of silicone, the bark was dried again at $35{ }^{\circ} \mathrm{C}$ for 8 hours; then the samples were weighed again in order to determine the mass of the insulating layer of particular bark samples. In the next stage, the insulated samples were placed in desiccators, partly filled with water, in which relative air humidity was $96 \%$. Next, individual bark samples were control-weighed every 2 days until they reached constant mass, which allowed for determination of actual bark hygroscopicity $S_{\mathrm{HA}}$ and the respective relative moisture $M$. After reaching maximum hygroscopicity, the samples secured with silicone were placed in containers with water for 4 weeks in order to determine their maximum water storage capacity. After that period, the samples were placed vertically in desiccators partly filled with water, where they underwent the process of gravity drainage. On completion of the drainage process, individual samples were weighed and, after removal of the insulating layer, they underwent 24-hour drying at $105^{\circ} \mathrm{C}$.

Actual hygroscopicity $S_{\mathrm{HA}}$ of individual bark samples, expressed in $\mathrm{mm}$ of the water column in a bark layer with the thickness of $1 \mathrm{~cm}$, was calculated using the formula (eqn. 4):

$$
S_{H A}=\frac{M_{H}-M_{S}}{V} \cdot 10
$$

where $M_{\mathrm{H}}$ is the mass of a bark sample determined in the state of maximum hygroscopicity (g), $M_{\mathrm{s}}$ is the dry mass of a bark sample determined after its drying at $105{ }^{\circ} \mathrm{C}(\mathrm{g}), V$ is the volume of a sample $\left(\mathrm{cm}^{3}\right)$ determined as the ratio of the dry mass of bark $M_{\mathrm{s}}$ to its bulk density $\rho_{\mathrm{d}}$, and 10 is a factor of conversion into $\mathrm{mm}$ of $\mathrm{H}_{2} \mathrm{O}$.

An analogous formula was used to determine maximum water capacity of bark (eqn. 5):

$$
S_{V}=\frac{M_{W}-M_{S}}{V} \cdot 10
$$

where $S_{\mathrm{v}}$ is the maximum water capacity of bark $\left(\mathrm{mm} \mathrm{H}_{2} \mathrm{O}\right.$ in a bark layer with the thickness of $1 \mathrm{~cm}), M_{\mathrm{w}}$ is the mass of a bark sample determined in the state of maximum 
filling with water (g).

Relative moisture of bark $M(\%)$, corresponding to its actual hygroscopicity $S_{\mathrm{HA}}$, was calculated using the formula (eqn. 6):

$$
M=\frac{M_{H}-M_{S}}{M_{S}} \cdot 100
$$

\section{Data analysis}

Statistical data analysis was conducted with the use of the software package STATISTICA $^{\circledast}$ v.10.0 (StatSoft Inc., Tulsa, OK, USA). Differences in specific densities $\rho_{\mathrm{s}}$ and the actual hygroscopicity of bark $S_{\mathrm{HA}}$ between particular forest tree species was tested by means of one-way ANOVA and the post-hoc Tukey's test. Departure from normality of data was prior tested by the Shapiro-Wilk test, while the equality of variances by the Levene's test. In the case of variables showing non-normal distribution (bulk density $\rho_{\mathrm{d}}$, total porosity $T P$, relative moisture $M$, maximum water capacity $S_{v}$ and the share of actual hygroscopicity in the maximum water storage capacity of bark), differences were tested using the non-parametric Kruskal-Wallis test and the Dunn post-hoc test. All differences were tested at the significance level $\alpha=0.05$.

Analysis of the relation of the share of actual hygroscopicity $S_{\mathrm{HA}}$ in water storage capacity $S_{\mathrm{v}}$ to the physical and retention properties of bark was conducted by means of linearized non-linear regression. Independent variables were selected on the basis of the corrected coefficient of determination $\left(R_{a d j}^{2}\right)$, the standard estimation error, distribution of residual values and the distribution of residual values in relation to values predicted by the equation of regression. The redundancy of variables was evaluated on the basis of the variance inflation factor (VIF) calculated as follows (eqn. 7):

$$
V I F_{j}=\frac{1}{1-R_{j}^{2}}
$$

where $R_{\dot{j}}^{2}$ is the coefficient of determination of a given variable $X_{\mathrm{j}}$ for the other explanatory variables in the model.

\section{Results}

\section{Physical properties of bark}

\section{Specific density and bulk density}

The distribution of specific density $\rho_{\mathrm{s}}$ and bulk density $\rho_{\mathrm{d}}$, determined for the bark of individual forest tree species is presented in Fig. 1a and Fig. 1b. Specific density of bark $\rho_{\mathrm{s}}$ ranges from $1.212 \mathrm{~g} \mathrm{~cm}^{-3}$ (L. decidua, $\mathrm{DBH}=15 \mathrm{~cm}$ ) to $1.562 \mathrm{~g} \mathrm{~cm}^{-3}$ (Q. robur, DBH $=29 \mathrm{~cm}$ ). No significant differences were found between particular tree species in terms of specific density of bark $\rho_{\mathrm{s}}$ (Fig. 1a); the lowest mean specific density $\rho_{\mathrm{s}}$ was obtained for the L. decidua bark (1.373 \pm $0.033 \mathrm{~g} \mathrm{~cm}^{-3}$ ), while the highest was observed for the $A$. pseudoplatanus bark $\left(1.434 \pm 0.011 \mathrm{~g} \mathrm{~cm}^{-3}\right)$.

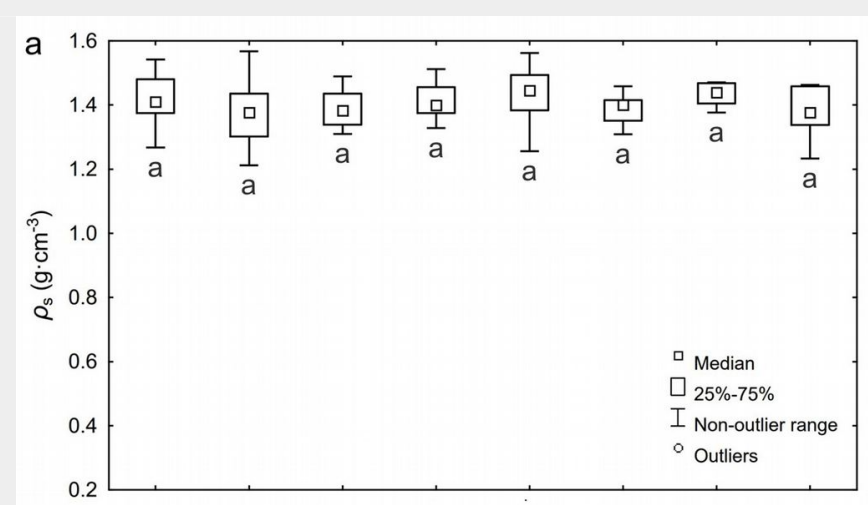

Fig. 1 - Range of variation of (a) specific density $\rho_{\mathrm{s}}$, (b) bulk density $\rho_{\mathrm{d}}$ and (c) total porosity $T P$ of the bark of the forest tree species analyzed. Different letters indicate significant differences between species after Tukey's or Dunn's

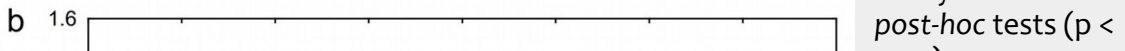
0.05).
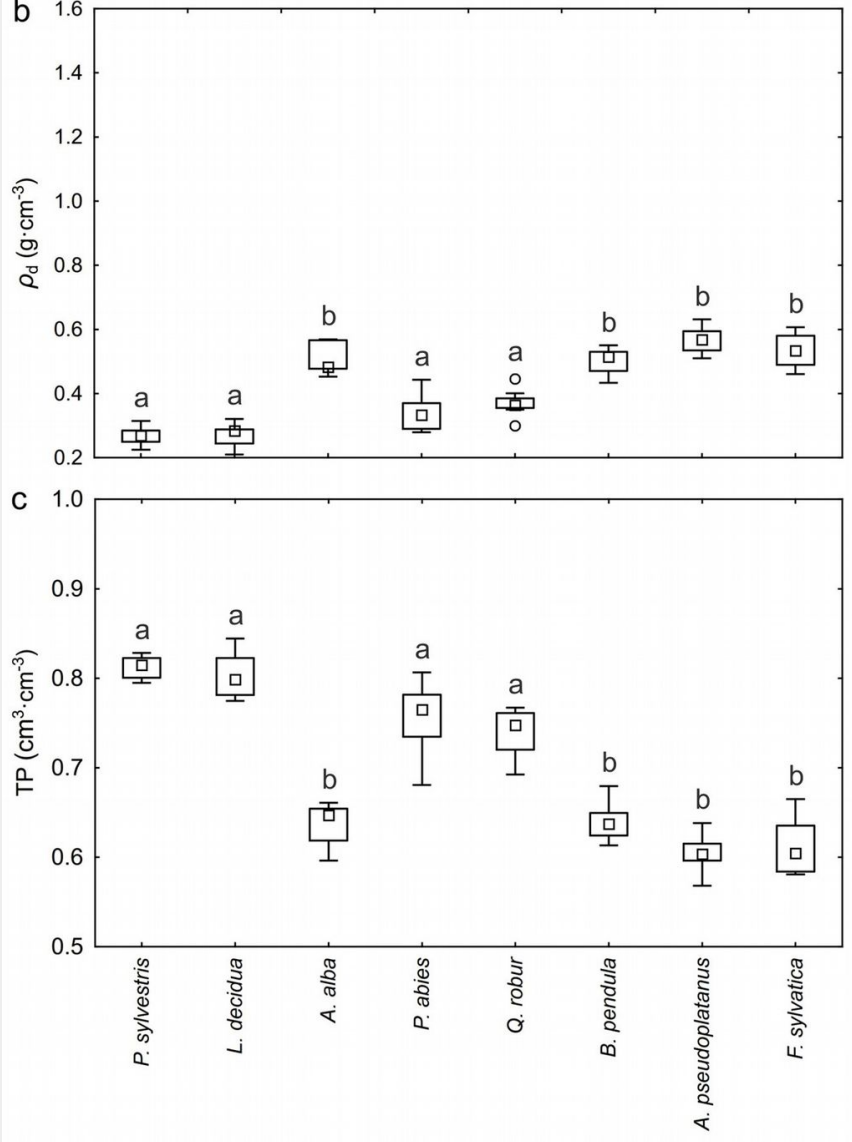

Bulk density of bark $\rho_{\mathrm{d}}$ showed values from $0.210 \mathrm{~g} \mathrm{~cm}^{-3}$ (L. decidua, $\mathrm{DBH}=35 \mathrm{~cm}$ ) to $0.631 \mathrm{~g} \mathrm{~cm}^{-3}$ (A. pseudoplatanus, $\mathrm{DBH}=$ $34 \mathrm{~cm}$ ). For the bark of all coniferous species considered jointly, the mean value of bulk density $\rho_{\mathrm{d}}$ amounted to $0.346 \mathrm{~g} \mathrm{~cm}^{-3}$, while for deciduous species it was $0.494 \mathrm{~g}$ $\mathrm{cm}^{-3}$. The highest variation of bulk density characterized the bark of $P$. abies (17.05\%), while the lowest was found for the bark of A. pseudoplatanus (6.99\%). The highest mean value of bulk density $\rho_{\mathrm{d}}$ was obtained for the bark of $A$. pseudoplatanus ( $0.567 \pm$ $0.040 \mathrm{~g} \mathrm{~cm}^{-3}$ ), while the lowest for the bark of $P$. sylvestris $\left(0.267 \pm 0.008 \mathrm{~g} \mathrm{~cm}^{-3}\right)$ and $L$. decidua $\left(0.269 \pm 0.011 \mathrm{~g} \mathrm{~cm}^{-3}\right)$.

\section{Total porosity}

The range of total porosity $T P$ of the bark of all forest tree species is presented in Fig. 1c. Porosity showed values ranging from $0.57 \mathrm{~cm}^{3} \mathrm{~cm}^{-3}$ (A. pseudoplatanus, DBH $=34$ $\mathrm{cm}$ ) to $0.84 \mathrm{~cm}^{3} \mathrm{~cm}^{-3}$ (L. decidua, $\mathrm{DBH}=21$ and $35 \mathrm{~cm}$ ). For the bark of all coniferous species considered jointly, the mean value of total porosity $T P$ was $0.75 \pm 0.01 \mathrm{~cm}^{3}$ $\mathrm{cm}^{-3}$, while for deciduous species it was $0.65 \pm 0.01 \mathrm{~cm}^{3} \mathrm{~cm}^{-3}$. The highest mean values of $T P$ were obtained for $P$. sylvestris bark $\left(0.81 \pm 0.01 \mathrm{~cm}^{3} \mathrm{~cm}^{-3}\right)$ and L. decidua $\left(0.80 \pm 0.01 \mathrm{~cm}^{3} \mathrm{~cm}^{-3}\right)$, while the lowest for A. pseudoplatanus $\left(0.60 \pm 0.01 \mathrm{~cm}^{3} \mathrm{~cm}^{-3}\right)$ and F. sylvatica bark $\left(0.61 \pm 0.01 \mathrm{~cm}^{3} \mathrm{~cm}^{-3}\right)$. For the bark of A. alba, P. abies, Q. robur and $B$. pendula, the mean values of total porosity TP were, respectively, $0.64 \pm 0.01$, $0.75 \pm 0.01,0.74 \pm 0.01$ and $0.64 \pm 0.01 \mathrm{~cm}^{3}$ $\mathrm{cm}^{-3}$.

\section{Actual hygroscopicity of bark}

The range of variation of actual hygroscopicity $S_{\mathrm{HA}}$ and the corresponding moisture $M$ of the bark of individual forest tree species is illustrated in Fig. 2a and Fig. 2b. 

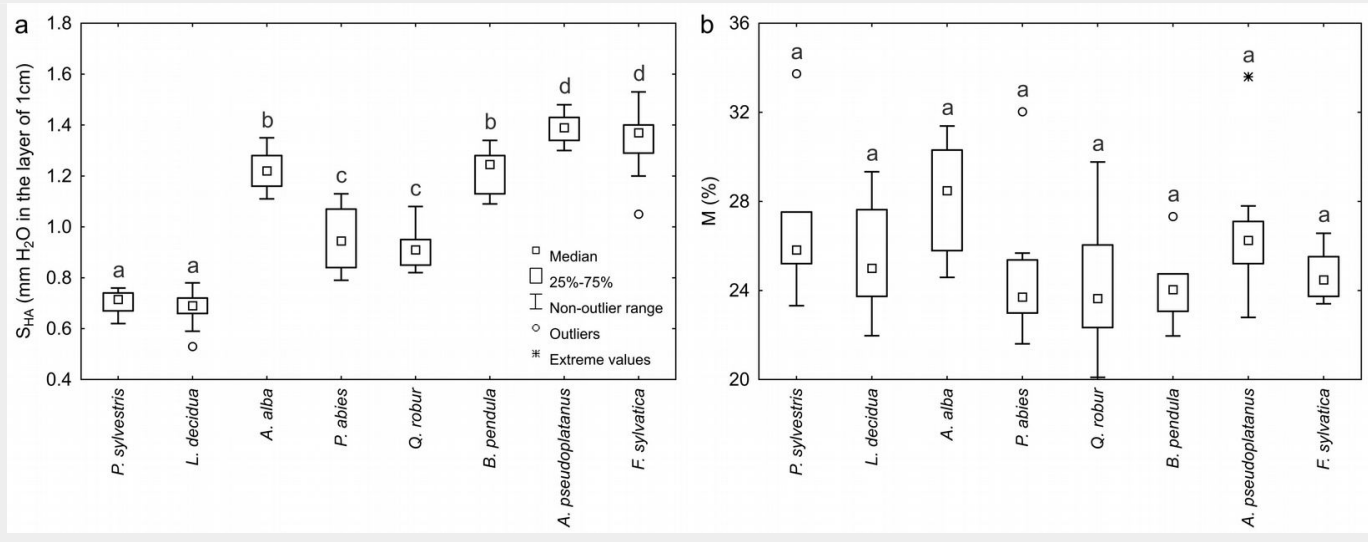

Fig. 2 - The range of variation of (a) actual hygroscopicity $S_{\mathrm{HA}}$ and (b) relative moisture $M$ (corresponding to actual hygroscopicity) of the bark of different forest tree species. Different letters indicate significant differences between species after Tukey's or Dunn's post-hoc tests $(\mathrm{p}<0.05)$.

Actual hygroscopicity $S_{\mathrm{HA}}$ ranged from 0.53 $\mathrm{mm}$ ( $\mathrm{L}$. decidua, $\mathrm{DBH}=35 \mathrm{~cm}$ ) to $1.53 \mathrm{~mm}$ of water ( $F$. sylvatica, DBH $=23 \mathrm{~cm}$ ) in the bark layer with the thickness of $1 \mathrm{~cm}$. The mean value of actual hygroscopicity $S_{\text {HA }}$ of the bark of all coniferous species considered jointly amounted to $0.89 \pm 0.04 \mathrm{~mm}$, while for deciduous species it was $1.21 \pm$ $0.04 \mathrm{~mm}$. The highest variation of $S_{\mathrm{HA}}$ characterized the P. abies bark (12.53\%) while the lowest was observed for the bark of $A$. pseudoplatanus (4.09\%). The highest mean values of actual hygroscopicity $S_{\mathrm{HA}}$ were obtained for $A$. pseudoplatanus bark (1.39 \pm $0.02 \mathrm{~mm})$ and F. sylvatica bark (1.33 \pm 0.04 $\mathrm{mm}$ ), while the lowest were found for $L$. decidua $(0.68 \pm 0.02 \mathrm{~mm})$ and $P$. sylvestris bark $(0.71 \pm 0.01 \mathrm{~mm})$. Mean hygroscopicity $S_{\mathrm{HA}}$ of the bark of A. alba, P. abies, Q. robur and $B$. pendula was, respectively: $1.22 \pm$ $0.03,0.95 \pm 0.04,0.92 \pm 0.02$ and $1.22 \pm$ $0.03 \mathrm{~mm}$. Significant differences in the bark $S_{\mathrm{HA}}$ were found between the majority of forest tree species (Fig. 2a).

Relative bark moisture $M$, corresponding to its actual hygroscopicity $S_{\mathrm{HA}}$, ranged from $20.1 \%$ (Q. robur, $D B H=29 \mathrm{~cm}$ ) to $33.7 \%$ $(P$. sylvestris, $\mathrm{DBH}=5 \mathrm{~cm})$. The mean value of $M$ of all coniferous species considered jointly was $26.4 \pm 0.5 \%$, while in the case of deciduous species it was $25.1 \pm 0.4 \%$. The highest variation of $M$ was observed for the bark of Q. robur (12.48\%), P. abies (12.37\%) and P. sylvestris (12.33\%), while the lowest for the bark of F. sylvatica (4.67\%). The mean values of the bark $M$ were similar in the case of $P$. sylvestris, $L$. decidua, $A$. alba, P. abies, Q. robur, B. pendula, A. pseudoplatanus and F. sylvatica $(26.8 \pm 1.2,25.7 \pm$ $0.9,28.2 \pm 0.7,24.6 \pm 1.0,24.2 \pm 1.1,24.2 \pm$ $0.8,26.6 \pm 0.9$ and $24.7 \pm 0.4 \%$, respectively). On the basis of the Kruskal-Wallis test, no statistically significant differences were noted in relative bark moisture $M$ between particular forest tree species (Fig. 2b).

Actual hygroscopicity $S_{\mathrm{HA}}$ showed a strong dependency on bulk density: along with an increase of density, the hygroscopic abilities of bark also grow (Fig. 3a). An opposite dependency was noted in relation to total porosity $T P$ (Fig. 3b). Contrastingly, bark hygroscopicity, expressed in relative units, did not show any relation to the physical properties of bark (Fig. $3 \mathrm{C}$ and Fig. 3d).
The share of actual hygroscopicity in maximum water storage capacity of bark

The range of variation of maximum water capacity $S_{\vee}$ of the bark of particular forest tree species is presented in Fig. 4a. $S_{\mathrm{v}}$ rangeg from $3.60 \mathrm{~mm}$ (B. pendula, $\mathrm{DBH}=9$ $\mathrm{cm})$ to $7.39 \mathrm{~mm}$ (P. abies, DBH $=25 \mathrm{~cm})$ of water in a bark layer with the thickness of 1 $\mathrm{cm}$. The mean value of the bark $S_{\mathrm{v}}$ of all coniferous species considered jointly amounted to $5.83 \mathrm{~mm}$, while for deciduous species it was $5.76 \mathrm{~mm}$. The highest variation of water storage capacity characterized the bark of $P$. sylvestris (18.1\%) and $L$. decidua (17.6\%), while the lowest was found for F. sylvatica bark (6.0\%). The highest mean value of $S_{\mathrm{v}}$ was obtained for the bark of $P$. abies $(6.58 \pm 0.17 \mathrm{~mm})$, while the lowest for the bark of B. pendula ( $4.77 \pm$ 0.19 ). For the bark of $P$. sylvestris, $L$. decidua, A. alba, Q. robur, A. pseudoplatanus and $F$. sylvatica, the mean value of water storage capacity $S_{v}$ was, respectively: 5.39 $\pm 0.31,5.35 \pm 0.30,5.99 \pm 0.15,5.85 \pm 0.15$, $6.28 \pm 0.18$ and $6.15 \pm 0.12 \mathrm{~mm}$.

The range of variation of the share of actual hygroscopicity $S_{\text {HA }}$ in maximum wa-
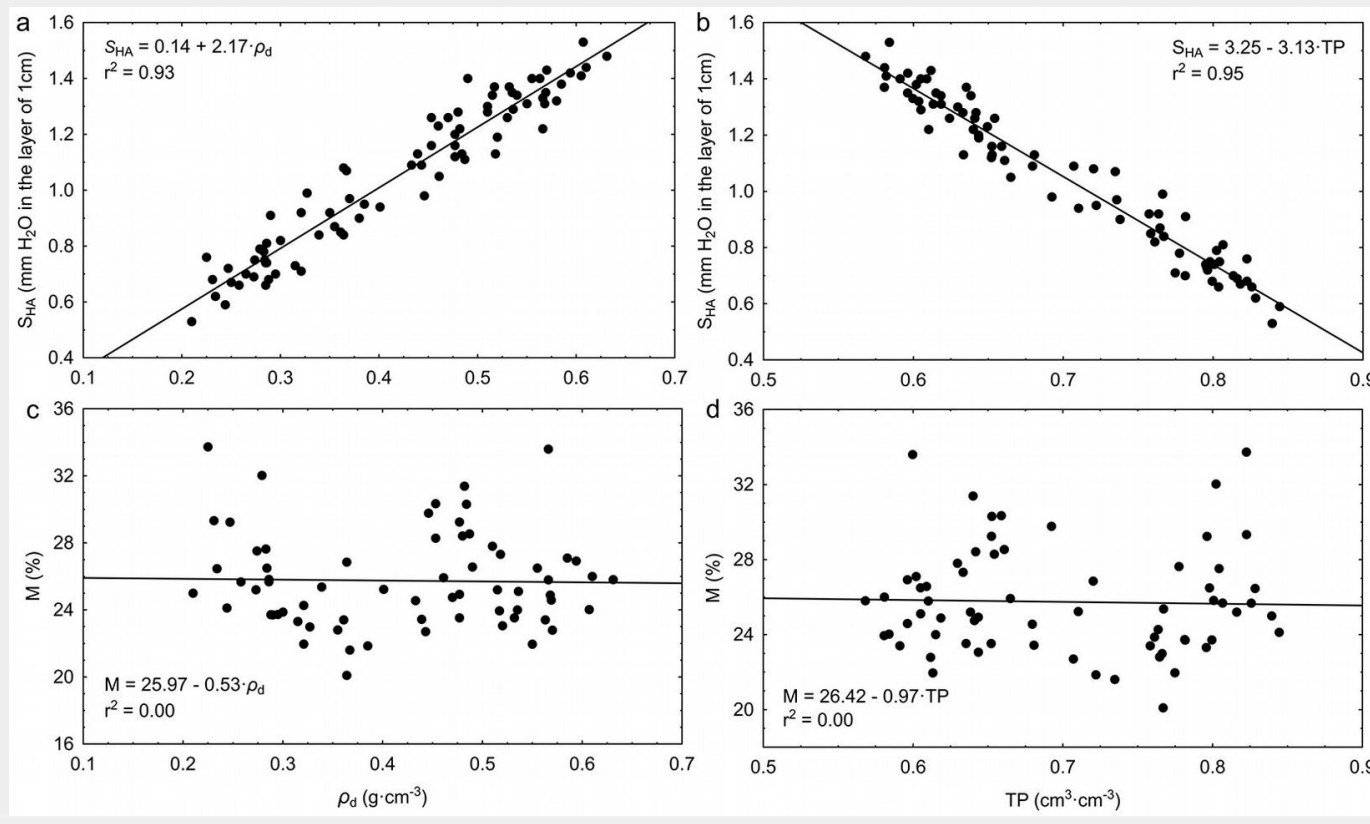

Fig. 3 - Relationships between: (a) actual hygroscopicity $S_{\mathrm{HA}}$ and bulk density $\rho_{\mathrm{d}}$; (b) actual hygroscopicity $S_{\mathrm{HA}}$ and total porosity $T P$; (c) relative moisture $M$ (corresponding to actual hygroscopicity $\left.S_{\mathrm{HA}}\right)$ and bulk density $\rho_{\mathrm{d}}$; (d) relative moisture $M$ and total porosity TP of bark of the analyzed forest tree species. 
Fig. 4 - The range of variation of (a) maximum water capacity $S_{v}$ and (b) the share of actual hygroscopicity $S_{\mathrm{HA}}$ in maximum water capacity $S_{\mathrm{v}}$ of the bark of particular forest tree species. Different letters indicate significant differences between species after Tukey's or Dunn's post-hoc tests $(p<0.05)$
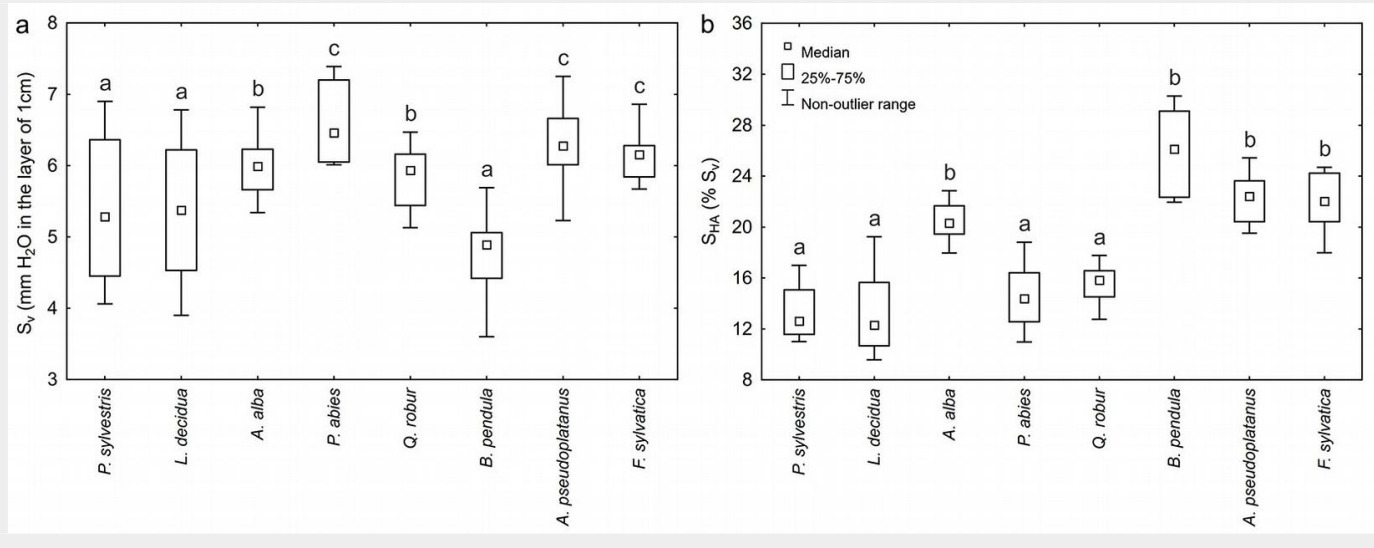

Tab. 1 - Parameter estimation of the relationship between the percentage of actual hygroscopicity out of the maximum water storage capacity $\left[S_{\mathrm{HA}}\left(\% S_{\mathrm{v}}\right)\right]$, total porosity $T P$ and maximum water storage capacity $S_{\mathrm{v}}$ of the bark (see eqn. 8).

\begin{tabular}{lcccccccc}
\hline Variable & $\begin{array}{c}\text { Parameter } \\
\text { value }\end{array}$ & SE & $\begin{array}{c}\text { Statistic } \\
\text { t-value }\end{array}$ & $\begin{array}{c}\text { Probability } \\
\text { level }\end{array}$ & $\begin{array}{c}\text { Partial } \\
\text { correlation }\end{array}$ & VIF & $\mathbf{R}_{\text {adj }}^{2}$ & $\begin{array}{c}\text { SE of } \\
\text { estimation }\end{array}$ \\
\hline Free term & 5.85 & 0.08 & 70.61 & 0.00 & - & - & & \\
$T P$ & -3.04 & 0.09 & -35.34 & 0.00 & -0.97 & 1.01 & 0.948 & 0.06 \\
$S$ & -0.15 & 0.01 & -16.87 & 0.00 & -0.89 & 1.01 & & \\
\hline
\end{tabular}

ter storage capacity of bark $S_{\mathrm{v}}$ of particular forest tree species is illustrated in Fig. $4 \mathrm{~b}$. Actual hygroscopicity $S_{\mathrm{HA}}$ constitutes from $9.6 \%$ (L. decidua, $\mathrm{DBH}=35 \mathrm{~cm}$ ) to $30.3 \%$ (B. pendula, $\mathrm{DBH}=9 \mathrm{~cm})$ of the maximum water storage capacity of bark $S_{\mathrm{v}}$. The average share of $S_{\mathrm{HA}}$ in $S_{\mathrm{V}}$ of the bark of all coniferous species considered jointly was 15.4 $\pm 0.60 \%$, while for deciduous species it was $21.4 \pm 0.70 \%$. The largest variation in the share of actual hygroscopicity $S_{\mathrm{HA}}$ in $S_{\mathrm{v}}$ characterized the bark of L. decidua (22.8\%) and $P$. sylvestris (17.1\%) while the lowest was observed for the bark of A. alba (8.1\%) and $A$. pseudoplatanus ( $8.9 \%)$. The bark of $B$. pendula had the highest mean share of hygroscopicity $S_{\mathrm{HA}}$ in water storage capacity $S_{\mathrm{v}}(25.9 \pm 1.10 \%)$, while L. decidua (13.1 \pm $0.94 \%)$ and $P$. sylvestris (13.4 $\pm 0.72 \%$ ) had the lowest mean share. For the bark of $A$. alba, P. abies, Q. robur, A. pseudoplatanus and F. sylvatica, the mean $S_{\mathrm{HA}}$ was, respectively: $20.4 \pm 0.53,14.6 \pm 0.76,15.7 \pm 0.49$, $22.3 \pm 0.63$ and $21.7 \pm 0.76 \%$.

The percentage of actual hygroscopicity of bark $S_{\mathrm{HA}}$ in water storage capacity $S_{\mathrm{v}}$ showed a dependency from the total porosity of bark and its maximum water storage capacity. This dependence is described by the following formula, which accounted for nearly $95 \%$ of the total variation (eqn. 8):

$$
S_{h a}\left(\% S_{V}\right)=e^{5.85-3.04 T P-0.15 S_{V}}
$$

where $S_{\mathrm{HA}}\left(\% S_{v}\right)$ is the share of actual hygroscopicity of bark in its maximum water capacity (\%), TP is the total porosity of bark $\left(\mathrm{cm}^{3} \mathrm{~cm}^{-3}\right)$ and $S_{\mathrm{v}}$ is the maximum water storage capacity of bark $\left(\mathrm{mm} \mathrm{H}_{2} \mathrm{O}\right.$ in a bark layer with the thickness of $1 \mathrm{~cm}$ ). Significance of the parameters of eqn. 8 is presented in Tab. 1.

\section{Discussion}

The lack of significant differences in specific density of bark between particular tree species implies that the variation in total porosity of the bark is mainly related to its bulk density. This may be proved by the results displayed in Fig. 1. On their basis it may be stated that differences in bulk density between particular tree species fairly corresponds to differences in their total porosity. Interspecies variation in bulk density of the bark was also reported by Bauer et al. (2010). According to Meyer et al. (1981), the density of inner bark may be lower than the density of outer bark, thus differences in the bulk density of bark between species may be related to different proportions of rhytidome to inner bark. According to Quilhó \& Pereira (2001), bulk density of bark along the stems of individual trees is less varied. These authors demonstrated that possible differences in the density of bark of Eucalyptus globules Labill. may be related to environmental conditions, affecting the structure and chemical properties of the bark (Wang et al. 1984).

The differences in the actual hygroscopicity of bark observed between species may be related not only to differences in their physical properties, but also to the chemical composition of cell walls, which is a species-related feature of bark. For example, the bark cellulose content in birch is 4 times smaller than in pine and spruce, while the suberin content is over 10 times higher. Further, pine bark contains nearly $16 \%$ more lignin than spruce bark (Grochowski 1990).

Interspecies variation of bark hygroscopicity had been indicated by Young (1938). He showed that among 20 tested tree species the highest hygroscopicity ex- pressed in relative units characterized the bark of Pinus sylvestris L. (40.1\%), while the bark of Carya opata (Mill.) K. Koch had the lowest (13.6\%). According to Kapur \& Narayanamurti (1934), the bark hygroscopicity of different species ranges from 22 to $28 \%$. As shown in Fig. 3, hygroscopicity expressed in relative units is neither related to the store of water in bark in its balance expression nor to its physical properties. The bark with higher density and lower porosity, while having the same moisture, usually contains more water than the bark with lower density. A similar pattern may be observed for forest soils. According to Kucza (2005), soil moisture changes expressed in relative units allow for determining the direction of changes, but no quantitative assessment of water balance is possible. In other words, soil water storage cannot be directly inferred from the relative ground moisture, as two soil sediments having the same relative moisture but differing in their granulometric composition and porosity may show different water storage capability. Based on the above reason, it may be concluded that relative moisture is a poor measure of water retention capabilities of the bark.

As shown in Fig. 4b, the actual hygroscopicity of bark may constitute a considerable share of its maximum water storage capacity, reaching even $30 \%$ in the case of birch. This implies that during rainfall bark retention may be reduced by as much as $10-30 \%$, depending on tree species. This also means that hygroscopicity of bark may constitute a significant component of the water balance of forest ecosystems. Therefore, the knowledge of actual hygroscopicity of the bark is an important stand parameter and the proposed method may be used for quantifying the degree of bark retention 
before rainfall occurrence.

It should be emphasized that our results are preliminary as the study was conducted only on bark samples collected at tree breast height. Hutchinson \& Roberts (1981) showed that stemflow is generated mainly in the top tree crowns, likely due to a lower water storage capacity of the bark which is usually thinner (Levia \& Wubbena 2006). Vertical variation of the bark water storage capacity has been reported by Levia \& Wubbena (2006) and calls for the analysis of the vertical variation of bark hygroscopicity. However, considering the strong dependence of bark hygroscopicity on its physical properties (Fig. 3) as well as the low variation of bark bulk density along the stems of individual trees (Quilhó \& Pereira 2001), it may be assumed that the vertical variation of bark hygroscopicity could be very small, while its share in total water storage capacity should increase with the height along the stem.

The main differences found in bark hygroscopicity among species concern its maximum values (Fig. 2a). Wood hygroscopicity exhibits a peculiar dynamics, dependent on air temperature and humidity, among others (Krzysik 1974, Kubiak \& Laurow 1994). Considering the inter-specific variation in bark morphology and its variability which increases with tree age (llek \& Kucza 2014), it may be assumed that the dynamics of bark hygroscopicity also depends on tree species and age. Furthermore, bark hygroscopicity dynamics is expected to modify the microclimate in the forest. Indeed, latent heat is released to the atmosphere during steam condensation in contact with bark or it is absorbed from the atmosphere during water evaporation from bark. For that reason, water absorption/evaporation by/from the bark may be an important factor affecting air temperature and humidity within a stand. However, the physical evaluation of that process requires further research focused on the dependence of the dynamics of bark hygroscopicity on changes in air humidity and temperature, on species and age of the stand as well as on the total surface of the bark of tree stems and branches.

\section{Conclusions}

In this study, the variation of several physical properties of the bark were analyzed in Pinus sylvestris, Larix decidua, Abies alba, Picea abies, Quercus robur, Fagus sylvatica, Acer pseudoplatanus and Betula pendula. It was found that the bark of all coniferous species is generally characterized by a lower bulk density and a higher total porosity compared to deciduous species.

Actual hygroscopicity of bark (expressed in balance units) increased with increasing bulk density and decreasing total porosity of the bark. We found that relative moisture is a poor measure of bark water retention capability. Significant differences in actual hygroscopicity of the bark were found between most of the forest tree species considered, while no differences were observed in terms of relative bark moisture. Depending on tree species, actual hygroscopicity may reach $10-30 \%$ of the maximum water storage capacity of the bark.

\section{Acknowledgments}

This research was financed by the Ministry of Science and Higher Education of the Republic of Poland (grant number: $\mathrm{BM} / 4419 / \mathrm{KIL} / 12$ ). The authors thank two anonymous reviewers for their many valuable and helpful suggestions.

\section{References}

Aboal JR, Jiménez $M$, Morales $D$, Hernández JM (1999). Rainfall interception in laurel forest in the Canary Islands. Agricultural and Forest Meteorology 97: 73-86. - doi: 10.1016/S0168-1923 (99)00083-0

Antkowiak L (1997). Wykorzystanie kory niektórych drzew i krzewów [The use of the bark of some trees and shrubs]. Wydawnictwo Akademii Rolniczej im. Augusta Cieszkowskiego, Poznan, Poland, pp. 1-10. [in Polish]

Barbier S, Balandier P, Gosselin F (2009). Influence of several tree traits on rainfall partitioning in temperate and boreal forests: a review. Annals of Forest Science 66 (6): 1-11. - doi: 10.1051/forest/2009041

Barlow J, Lagan BO, Peres CA (2003). Morphological correlates of fire- induced tree mortality in a central Amazonian forest. Journal of Tropical Ecology 19: 291-299. - doi: 10.1017/S0266467 403003328

Bates JW, Brown DH (1981). Epiphyte differentiation between Quercus petraea and Fraxinus excelsior trees in a maritime area of South West England. Vegetatio 48 (1): 61-70. - doi: 10.1007/B Fo0117362

Bauer G, Speck T, Blömer J, Bertling J, Speck O (2010). Insulation capability of the bark of trees with different fire adaptation. Journal of Materials Science 45: 5950-5959. - doi: 10.1007/s108 53-010-4680-4

Biggs AR (1992). Anatomical and physiological responses of bark tissues to mechanical injury. In: "Defense mechanisms of woody plants against fungi” (Blanchette RA, Biggs AR eds). Springer, Berlin-Heidelberg, Germany, pp. 1340. - doi: 10.1007/978-3-662-01642-8_2

Brown JH, Barker AC (1970). An analysis of throughfall and stemflow in mixed oak stands. Water Resources Research 6 (1): 316-323. - doi: 10.1029/WRoo6io01po0316

Bryant ML, Bhat S, Jacobs JM (2005). Measurements and modeling of throughfall variability for five forest communities in the southeastern US. Journal of Hydrology 312: 95-108. - doi: 10.1016/j.jhydrol.2005.02.012

Crockford RH, Richardson DP (2000). Partitioning of rainfall into throughfall, stemflow and interception: effect of forest type, ground cover and climate. Hydrological Processes 14: 2903-2920. - doi: 10.1002/1099-1085(200011/12) 14:16/17<2903::AID-HYP126>3.0.CO;2-6

Grochowski W (1990). Uboczna produkcja lesna [Non-wood forest products]. PWN, Warszawa, Poland, pp. 50-100. [in Polish]

Hengst GE, Dawson JO (1994). Bark properties and fire resistance of selected tree species from the central hardwood region of North America. Canadian Journal of Forest Research 24 (4): 688-696. - doi: 10.1139/x94-092

Herwitz SR (1985). Interception storage capacities of tropical rainforest canopy trees. Journal of Hydrology 77: 237-252. - doi: 10.1016/00221694(85)90209-4

Hutchinson I, Roberts MC (1981). Vertical variation in stemflow generation. Journal of Applied Ecology 18: 521-527. - doi: 10.2307/2402413

Ilek A, Kucza J (2014). Hydrological properties of bark of selected forest tree species. Part I: the coefficient of development of the interception surface of bark. Trees 28: 831-839. - doi: 10.100 7/s00468-014-1101-3

Kapur SN, Narayanamurti D (1934). Hygroscopicity of tree barks. Indian Forester 60 (10): 702707.

Klamerus-Iwan A (2014). Potential interception in laboratory condition under simulated rain with low intensity. Sylwan 158 (4): 292-297.

Kozlowski TT (1992). Carbohydrate sources and sinks in woody plants. The Botanical Review 58: 108-222. - doi: $10.1007 / B F 02858600$

Kozlowski R, Józwiak MA, Borowska E (2010). Porównanie wybranych metod do obliczania wysokosci opadu splywajacego po pniach [Comparison of selected methods for calculation of stemflow volume]. Monitoring Srodowiska Przyrodniczego, Kieleckie Towarzystwo Naukowe, Kielce 11: 25-33. [in Polish]

Kraszkiewicz A (2009). Analiza wybranych wlasciwosci chemicznych drewna i kory robinii akacjowej (Robinia pseudoacacia L.) [Analysis of selected chemical properties of wood and bark of black locust (Robinia pseudoacacia L.)]. Inzynieria Rolnicza 8 (117): 69-75. [in Polish]

Krzysik F (1974). Nauka o drewnie [The science of wood]. PWRiL, Warszawa, Poland, pp. 95150. [in Polish]

Kubiak M, Laurow Z (1994). Surowiec drzewny [Wood raw material]. Fundacja Rozwój SGGW, Warszawa, Poland, pp. 275-278. [in Polish]

Kucza J (2005). Theoretical and practical aspects of calculating the water storage in forest soils. Part I. Non-skeletal soils. Sylwan 9: 24-33.

Kuusinen M (1996). Epiphyte flora and diversity on basal trunks of six old- growth forest tree species in southern and middle boreal Finland. The Lichenologist 28 (5): 443-463. - doi: 10.1017/ So024282996000588

Legates DR, Levia DF, Van Stan II JT, Velasco Herrera VM (2014). Using wavelet analysis to examine bark microrelief. Trees 28: 413-425. - doi: 10.1007/s00468-013-0959-9

Levia DF, Frost EE (2003). A review and evaluation of stemflow literature in the hydrologic and biogeochemical cycles of forested and agricultural ecosystems. Journal of Hydrology 274: 1-29. - doi: 10.1016/So022-1694(02)00399-2

Levia DF, Germer S (2015). A review of stemflow generation dynamics and stemflow-environment interactions in forests and shrublands. Reviews of Geophysics 53 (3): 673-714. - doi: 10.1002/2015RG000479

Levia DF, Herwitz SR (2005). Interspecific variation of bark water storage capacity of Tyree deciduous tree species in relation to stemflow yield and solute flux to forest soils. Catena 64 : 117-137. - doi: 10.1016/j.catena.2005.08.001 
Levia DF, Van Stan IIJT, Mage SM, Kelley-Hauske PW (2010). Temporal variability of stemflow volume in a beech-yellow poplar forest in relation to tree species and size. Journal of Hydrology 380: 112-120. - doi: 10.1016/j.jhydrol.2009. 10.028

Levia DF, Wubbena NP (2006). Vertical variation of bark water storage capacity of Pinus strobus L. (Eastern white pine) in southern Illinois. Northeastern Naturalist 13 (1): 131-137. - doi: 10.1656/1092-6194(2006)13[131:VVOBWS]2.0.CO ;2

Liu SG (1997). A new model for the prediction of rainfall interception in forest canopies. Ecological Modelling 99: 151-159. - doi: 10.1016/S03043800(97)01948-0

Llorens P, Gallart F (2000). A simplified method for forest water storage capacity measurement. Journal of Hydrology 240: 131-144. - doi: 10.1016/So022-1694(00)00339-5

Llorens P, Poch R, Latron J, Gallart F (1997). Rainfall interception by a Pinus sylvestris forest patch overgrown in a Mediterranean mountainous abandoned area. I. Monitoring design and results down to the event scale. Journal of Hydrology 199: 331-345. - doi: 10.1016/So022-16 94(96)03334-3

Meyer RW, Kellogg RM, Warren WG (1981). Relative density, equilibrium moisture content, and dimensional stability of western hemlock bark. Wood and Fiber 13 (2): 86-96. [online] URL: http://wfs.swst.org/index.php/wfs/article/view/ 159

Öztürk S, Oran S (2011). Investigations on the bark pH and epiphytic lichen diversity of Quer- cus taxa found in Marmara Region. Journal of Applied Biological Sciences 5 (1): 27-33.

Pinard MA, Huffman J (1997). Fire resistance and bark properties of trees in a seasonally dry forest in eastern Bolivia. Journal of Tropical Ecology 13 (5): 727-740. - doi: 10.1017/S02664674 00010890

PKN-CEN-ISO/TS-17892-3 (2009). Badania geotechniczne. Badania laboratoryjne gruntów. Czesć 3: Oznaczanie gestosci wlasciwej - Metoda piknometru [Geotechnical studies. Laboratory tests of the soil. Part 3: Determination of specific density - The pycnometer method]. Polski Komitet Normalizacyjny, Poland, pp. 1-11. [in Polish]

Prosinski S (1984). Chemia drewna [Chemistry of wood]. PWRiL, Warszawa, Poland, pp. 20-65. [in Polish]

Quilhó T, Pereira H (2001). Within and betweentree variation of bark content and wood density of Eucalyptus globulus in commercial plantations. IAWA Journal 22 (3): 255-265. - doi: 10.1163/22941932-90000283

Raczkowski J (1979). Swelling properties of bark. Wood Science and Technology 13 (3): 187-196. doi: 10.1007/BFo0350223

Schulz H, Popp P, Huhn G, Stärk HJ, Schüürmann $G$ (1999). Biomonitoring of airborne inorganic and organic pollutants by means of pine tree barks. I. Temporal and spatial variations. Science of The Total Environment 232 (1): 49-58. doi: 10.1016/S0048-9697(99)00109-6

Stephenson SL (1989). Distribution and ecology of myxomycetes in temperate forests. II. Patterns of occurrence on bark surface of living trees, leaf litter, and dung. Mycologia 81: 60621. - doi: $10.2307 / 3760136$

Trampler T, Kliczkowska A, Dmyterko E, Sierpinska A (1990). Regionalizacja przyrodniczo-lesna na podstawach ekologiczno-fizjograficznych [The nature and forest regionalisation on the ecological and physiographic basics]. PWRiL, Warszawa, Poland, pp. 51-65. [in Polish]

Van Stan JT, Jarvis MT, Levia DF (2010). An automated instrument for the measurement of bark microrelief. IEEE Transactions on Instrumentation and Measurement 59: 491-493. - doi: 10.1109/TIM.2009.2031338

Van Stan JT, Lewis ES, Hildebrandt A, Rebmann C, Friesen J (2015). Impact of interacting bark structure and rainfall conditions on stemflow variability in a temperate beech-oak forest, central Germany. Hydrological Sciences Journal 61 (11): 2071-2083. - doi: 10.1080/02626667.2015. 1083104

Voigt GK (1960). Distribution of rainfall under forest stands. Forest Science 6 (1): 2-10.

Voigt GK, Zwolinski MJ (1964). Absorption of stemflow by bark of young red and white pines. Forest Science 10: 277-282. [online] URL: http://www.ingentaconnect.com/content/saf/fs /1964/00000010/00000003/art00006

Wang S, Littell RC, Rockwood DL (1984). Variation in density and moisture content of wood and bark among twenty Eucalyptus grandis progenies. Wood Science and Technology 18 (2): 97-100. - doi: 10.1021/eso0121a718 Young C (1938). Acidity and moisture in tree bark. Proceedings of the Indiana Academy of Science 47: 106-115. 